whole inquiry, and which I have overlooked in Mr. Darwin's books if it is to be found there, is a discussion of the causes which produce sterility and those which favour fertility in races. He no doubt discusses with ingenuity the problem of the sterility of mules and of crosses between different races, but I have nowhere met with the deeper and more inuprrtant discussion of the general causes that induce or check the increase of races. The facts upon which I rely are very common-place, and are furnished by the smallest plot of garden or the narrowest experience in breed. ing domestic animals. The gardener who wants his plants to blossom and fruit takes care that they shall avoid a vigorous growth. He knows that this will inevitably make them sterile; that either his trees will only bear distorted flowers, that they will have no seed, or bear no blossoms at all. In order to induce flowers and fruit, the gardener checks the growth and vigour of the plant by pruning its roots or its branches, depriving it of food, \&c., and if he have a stubborn pear or peach tree which has long refused to bear fruit, he adopts the hazardous, but often most successful, plan of ringing its bark. The large fieshy melons or oranges have few seeds in them. The shrivelled starvelings that grow on decaying branches are full of seed. And the rule is universally reccgnised among gardeners as applying to all kinds of cultivated plants, that to make them fruitful it is necessary to check their growth and to weaken them. The law is no less general among plants in a state of nature, where the individuals growing in rich soil, and which are well-conditioned and growing vigorously, have no flowers, while the starved and dying on the sandy sterile soil are scattering seed everywhere.

On turning to the animal kingdom, we find the law no less true. "Fat hens won't lay," is an old fragment of philosophy. The breeder of sheep and pigs and cattle knows very well that if his ewes and sows and cows are not kept lean they will not breed; and as a startling example I am told that to induce Alderney cows, which are bad breeders, to be fertile they are actually bled, and so reduced in condition. Mr. Doubleday who wrote an admirable work in answer to Malthus, to which I am very much indebted, has adduced overwhelming evidence to show that what is commonly known to be true of plants and animals is especially true of man. He has shown how individuals are affected by generous diet and good living, and also how classes are so affected. For the first time, so far as I know, he showed why population is thin and the increase small in countries where flesh and strong food is the ordinary diet, and large and increasing rapidly where fish or vegetable or other weak food is in use; that everywhere the rich, luxurious, and well fed classes are rather diminishing in numbers or stationary; while the poor, under-fed, and hard-worked are very fertile. The facts are excceedingly numerous in support of this view, and shall be quoted in your pages if the result is disputed. This was the cause of the decay of the luxurious power of Rome, and of the cities of Mesopotamia. These powers succumbed not to the exceptional vigour of the barbarians, but to the fact that their populations had diminished, and were rapidly being extinguished from internal causes, of which the chief was the growing sterility of their inhabitants.

The same cause operated to extinguish the Tasmanians and other savage tribes which have decayed and died out, when brought into contact with the luxuries of civilisation, notwithstanding every effort having been made to preserve them. In a few cases only have the weak tribes been supplanted by the strong, or weaker individuals by stronger; the decay has been internal, and of remoter origin. It has been luxury and not want; too much vigour and not too little, that has eviscerated and destroyed the race. If this law then be universal both in the vegetable and animal kingdoms, a law too, which does not operate on individuals and in isolated cases only, but universally, it is surely incumbent upon the supporters of the doctrine of Natural Selection, as propounded by Mr. Darwin, to meet and to explain it, for it seems to me to cut very cleeply into the foundations of their system. If it be true that, far from the strong sur viving the weak, the tendency among the strong, the well fed, and highly favoured, is to decay, become sterile, and die out, while the weak, the under-fed, and the sickly are increasing at a proportionate rate, and that the fight is going on everywhere among the individuals of every race, it seems to me that the theory of Natural Selection, that is, of the persistence of the stronger, is false, as a general law, and true only of very limited and exceptional cases. This paper deals with one difficulty only, others may follow if this is acceptable.

Derby liouse, Eccles

\section{Ocean Currents}

Mr. Proctor concludes his letter on Ocean Currents, in NATURE for June 15, with the remark that in theories respecting oceanic circulation "the vast distance separating the Polar from the Equatorial regions must not be overlooked." Will you allow me to point out to him that in the experiment he suggests, that vast distance is entirely overlooked; that, in fact, any such experiment, with whatever difference of detail it may be performed, whether in his cylinder or in Dr. Carpenter's trough, in no way illustrates the natural condition of things, and in no way tends to answer that objection to the "temperature" theory of currents which is founded on the infinitesimal nature of the thermometric gradients. The difference of temperature between Arctic and Equatorial water is about $50^{\circ} \mathrm{F}$., or $1^{\circ} \mathrm{F}$. in 100 miles; or, reducing it to smaller units suitable for an experiment, is $\frac{1}{600000}$ of a degree in one foot; this, if the experimental trough is five feet long, or if the cylinder is ten feet in diameter, gives an extreme difference of $\frac{1}{120000}$ of a degree of Fahrenheit's scale. Can such a difference be represented in any experiment? I think not; but no experiment which shows a much greater relative difference can be accepted as satisfactory for it is the infinitesimal nature of the thermometric gradient existing in the ocean that consticutes the physical objection to the temperature theory. There are other objections which I will not allude to now; but it is manifestly no answer to this one objection to show that under certain other circumstances-which bear no resemblance in degree to those of nature-hot water and cold will establish a circulation. I, for one, have, for a good many years, been perfectly well aware that they will; but I doubt if it has ever been shown that a sensible motion will result from a. thermometric gradient of $\frac{1}{\text { o }} 00 \mathrm{~d}$ of a degree in a foot.

\section{J. K. LAUGHTON}

\section{Alpine Floras}

THE fact mentioned in last week's NATURE of the absence of any Alpine flora on the Atlas Mountains, Morocco, though disappointing, is interesting. It seems to show that, during the glacial period, icebergs did not drift to the Atlas. This, how ever, must have been from local causes only. Mr. Wallace found a European flora on a mountain in the Eastern Archipelago-I think in Borneo-which, most probably, must have got there during the glacial period.

Old Forge, Dunmurry, Co. Antrim, June is

\section{A Suggestion}

Is it possible that the following facts may account for the presence of Elastrus dolosus in the Azores? At all events, I offer them as suggestive, and for the information of Messrs. Wallace, Godman, Murray, Crotch, \&c.

Lawrence Almeida, son of the first Portuguese Viceroy in India, was the first Eurupean known to visit the coast of Madagascar in the year 1506. The Portuguese circumnavigated the whole island within two years, and subsequently constantly anchored at it in their voyages to the East Indits. They also established a settlement on a steep rock on the bank of the river Franchere and near the village of Hatore, in the province of Anosi (i.e., at the south-eatern extremity of the island). The valuable timber, as ebony, as well as the rich dye-woods, would be well worth taking to Europe, and thus doubtless afforded a conveyance for living larval or pupal Elaters, without any rare or improbable concurrence of events, to the Portuguese islands in the Atlantic. Many of the extremely beautiful and attractive flowering shrubs and plants would also not improbably be forwarded to Europe by the same route, in which some Elaterida might find shelter. Is the lapse of 300 years sufficient to account for change of development?

Southsea

S. P. OUIVER

\section{HYDROUS SILICATES INZECTING THE PORAS OF FOSSILS}

R. T. STERRY HUNT directed attention some time ago* to a remarkable limestone of Silurian age from Pole Hill, New Brunswick, in which I had found the

* Proceedings of the Natural History Society of Montreal, 